\title{
Western
}

\section{Intersectional Grievances in Care Work: Framing inequalities of gender, class and caste}

\author{
By: Preethi Krishnan
}

\begin{abstract}
How do social movements include or exclude intersectional grievances of individual participants? What do variations in framing within the movement tell us about including intersectional grievances? I address these questions by examining frames deployed by anganwadi (childcare) workers in India and their organized union's documented demands. I utilize a systemic inter-sectional approach to examine two specific grievances- - low wages and weakening of public provision of care - that lie at the intersection of gender, caste, class, and care work. Workers use intersectional frames to interpret grievances, as they experience intersectional inequalities of gender, caste, and class. Findings show that the union targets the state alone while workers target both state and society. As intersectional grievances are durable inequalities that traverse across the boundaries of state and society, social movement frames may need a broader prognosis that targets both state and society to include intersectional grievances.
\end{abstract}

Krishnan, P. (2020). Intersectional Grievances in Care Work: Framing inequalities of gender, class and caste. Mobilization: An International Quarterly, 25(4), 493-512. https://doi.org/10.17813/1086-671X-22-4-493

Publisher version of record available at: https://doi.org/10.17813/1086-671X-22-4-493.

Archived version from NC DOCKS available at: http://libres.uncg.edu/ir/wcu/listing.aspx?styp=ti\&id=35438. 


\title{
INTERSECTIONAL GRIEVANCES IN CARE WORK: FRAMING INEQUALITIES OF GENDER, CLASS AND CASTE*
}

\author{
Preethi Krishnan ${ }^{\dagger}$
}

\begin{abstract}
How do social movements include or exclude intersectional grievances of individual participants? What do variations in framing within the movement tell us about including intersectional grievances? I address these questions by examining frames deployed by anganwadi (childcare) workers in India and their organized union's documented demands. I utilize a systemic intersectional approach to examine two specific grievances-low wages and weakening of public provision of care - that lie at the intersection of gender, caste, class, and care work. Workers use intersectional frames to interpret grievances, as they experience intersectional inequalities of gender, caste, and class. Findings show that the union targets the state alone while workers target both state and society. As intersectional grievances are durable inequalities that traverse across the boundaries of state and society, social movement frames may need a broader prognosis that targets both state and society to include intersectional grievances.
\end{abstract}

Why and how social movements emerge when they do have been of central interest to social movement scholars. While earlier scholarship explained movement emergence as psychological discontent and "strain" in response to grievances (Smelser 1962), others argued that movement emergence varied even when grievances were constant (McAdam 1999). Since then, various frameworks have been used to explain social movement emergence - political opportunity structure and threats, resource mobilization, and the framing process (Benford and Snow 2000; McAdam 1999; McCarthy and Zald 1977). These seminal articles that focused on mobilizing and organizing often rendered grievances as irrelevant. Interestingly, in recent years, there has been more attention paid to the structure of grievances as critical to explaining movement emergence (Hechter, Pfaff, and Underwood 2016; McKane and McCammon 2018; Simmons 2014; Skotnicki 2019). Others have shown how framing and meaning making of grievances mattered (Danaher and Crawshaw 2019; Ferree 2003; Roy 2010). Grievances also provide key insights into our understanding of inequality, including intersectional inequality. The increasing focus on intersectionality in recent social movement scholarship (Fisher, Dow, and Ray 2017; Hurwitz 2019; Terriquez, Brenes, and Lopez 2018) is testimony to the need for merging insights from social movements and inequality, elevating our understanding of both. Examining grievances, particularly intersectional grievances, is critical to that attempt.

Paying attention to intersectional grievances and examining their inclusion and exclusion in official social movement documents may have implications for addressing inequality and for mobilizing support. This article makes two main claims. One, examining variations in frames, "the interpretive schemata" used by individuals and the movement organization (official documents), may provide insights into understanding how intersectional grievances are excluded and included in social movements (Goffman 1974; Snow and Benford 1992). Two, as intersectional grievances are durable inequalities that traverse across the boundaries of state and society (Tilly 1998), social movement frames may need a broader prognosis that targets both state and society to include those grievances. Indeed, it would be naive to assume that all stakeholders

\footnotetext{
* Please direct all correspondence to Preethi Krishnan, Assistant Professor of Sociology, Department of Anthropology and Sociology, McKee G8A, Western Carolina University, Cullowhee, NC 28723 or email pkrishnan@wcu.edu. This research was supported by a fellowship from the Purdue Research Foundation.

$\dagger$ I thank the anonymous reviewers of Mobilization whose comments helped improve this article significantly. Thanks to the many anganwadi workers, mothers, union leaders, and officers who shared their time, life, and space with me.
} 
in a movement utilize a singular static frame (Oliver and Johnston 2000; Gamson 2004; Ferree 2003). Yet, for a collective adoption of a frame that motivates action, "it must be shared by potential challengers in a public way" (Gamson 1992: 73). Collective action frames emphasize or redefine grievances to hold an external entity accountable and to motivate people to demand change from those entities (Benford 1993b; Snow and Benford 1992). To examine whether movements are inclusive of intersectional grievances, it may be useful to evaluate if and how collective action frames in official movement documents are representative of how people experience and interpret grievances. Drawing on the literature on framing, intersectionality, and grievances, this article addresses the following questions: How do social movement frames include or exclude intersectional grievances experienced by individual participants? How does the variation in framing within the movement influence how intersectional grievances are included or excluded in the movement?

I address these questions by analyzing the grievances of unionized anganwadi (childcare) workers in Tamil Nadu, India. Anganwadis are neighborhood childcare centers operating as part of the massive state program for childcare services run by the Indian government known as the Integrated Child Development Services (ICDS). In Tamil Nadu, other than for the executive director position, the ICDS system is entirely managed by women (Rajivan 2006). More than 54,000 anganwadis in Tamil Nadu provide food, care, and supplementary nutrition to children under six and their mothers. I draw on five months of ethnographic fieldwork, interviews with fifty anganwadi workers, mothers, union leaders, and state representatives, and union documents to show how frames vary within the movement across the documented charter of demands of the union, the union leaders, and individual childcare workers.

In particular, I examine two specific grievances-low wages and weakening of public provision of care - grievances that lie at the intersection of gender, caste, class, and care work. Examining how individual workers differ from and mirror the union frames demonstrate how movements include and exclude intersectional grievances. In claiming higher wages from the state, individual anganwadi workers and union leaders referred to the gendered phenomena of unwaged work and unequal wages when comparing their job (one which hires women exclusively) to other government jobs that included men. The union charter of demands seldom mentioned gender or caste. But, individual workers acknowledged that the union addressed their grievances related to wages, irrespective of the framing. However, individual workers did not report the same about their grievances related to weakening of public provision of care, a grievance that intersects with the caste structure. Individual workers identify how caste-based segregation is exacerbated by privatization, affecting the number of children coming to the anganwadi.

The difference lies in the prognosis aspect of the frame: who was considered responsible for mitigating the grievance. In the case of low wages, irrespective of framing, both individual workers and the union interpreted it as a state problem, a grievance that can be mitigated by the state providing higher wages. However, in the case of weakening of public provision of care, there was a mismatch. Individual workers framed weakening of public provision of care as a societal problem where privatization intersects with the caste structure. To mitigate the grievance, for individual workers, members of society had to stop segregating their children into private schools based on caste. In the union charter of demands, privatization was framed only as a state problem and did not call for societal change.

These findings highlight the challenges and possibilities of including intersectional grievances in social movement organizations. Individual participants may experience and express their grievances through an intersectional lens as their lived experiences are embedded in intersecting structures of gender, caste, and class. The intersectional aspect of grievances is especially pronounced in the case of care work given how the distribution of care is embedded in structures of gender, caste, and class. 


\section{CARE WORK: AN INTERSECTIONAL GRIEVANCE}

Under capitalism, social reproduction work necessary for the creation, well-being, and caring of people is not valued as much as work that contributes to profit making (Bhattacharya 2017). Given that care work is usually done by women, especially poor women minoritized by race, ethnicity, and citizenship (Razavi 2007), their grievances lie at the intersection of gender, race, class, citizenship, and caste (in India). In concrete terms, these grievances could be related to the relatively lower pay for care workers (Razavi 2007; Palriwala and Neetha 2010; England 2005), the unpaid and unrecognized care work done by women in the family (Federici 2012), and the lack of affordable, high quality care services that prevent women from participating in the labor force (Boeckmann, Misra, and Budig 2015). Even when women participate in the labor market, they experience a loss of pay in the form of motherhood penalty (Correll, Benard, and Paik 2007). State policies related to public provision of care matters to women, especially poor women. When care work is transferred from the state to the market, only wealthy women can afford market provided care. In contrast, poor women have to choose between lower income as they stay home to do care work or carry their children to their workplace even under unsafe conditions (Narayanan 2008). That poor, minoritized women are most affected by these policies, or lack thereof, demonstrates how grievances lie at the intersections of class, race, citizenship, and gender.

Examining variations in individual and organizational frames while attending to gender as structure (Risman 2004) and as relational (Scott 1986) demonstrates how distribution and recognition of care work in family and society is gendered. While gender analysis illuminates our understanding of women's experiences, it also refers to how women are affected in relation to men and, sometimes, because of men. In Tamil Nadu, where I conducted fieldwork, attitudes regarding gender and care work are especially skewed. In the National Family Health Survey 2015-2016, more than 55\% women and 36\% men agreed that "a husband is justified in hitting or beating his wife if she neglects the house or the children." Thus, the gendered distribution of care work is justified by a cultural narrative where both women and men believe that mothers are primary caregivers. Beyond considering women as primary caregivers, both men and women even justify violence against women if they are seen as not performing the role appropriately.

The belief that women are natural caregivers often means not recognizing care work as work (Federici 2012). Even in the paid care-work industry, the notion that caring is intrinsic to women's nature justifies lesser pay and demands for unwaged work, emotional and otherwise (England, Budig, and Folbre 2002; England 2005). In this context, voicing gendered grievances related to care work may be an uphill task. The nonrecognition of care work as work is visible even in paid care-work situations, as this article shows. While gender norms established women as primary caregivers, caste determines who is excluded from performing certain forms of care work.

Caste is a unique stratification system in India where power, status, and privilege is ascribed solely based on parentage or ancestry. Brahmins are the most socially privileged caste while those born into Dalit communities experience marginalization. In this article, I use the term Scheduled Caste (SC), the government label that refers to Dalits because most people I spoke to referred to themselves in that manner. While wealth distribution in Tamil Nadu correlates with caste privilege, the brutality is felt much beyond economic terms (IIPS and Macro International 2007b). Brahmins are afforded status and privilege through socially constructed notions of purity. By "othering" Dalits as inherently less pure and thereby not worthy of touch, brahmins created an enclosure of social privilege. Although untouchability practices are forbidden by law in India, caste-based notions of purity is deeply embedded in Indian society. Brahmins are the most privileged, but caste is a system of graded inequality where caste communities discriminate against other castes below them (Ambedkar 1917). Even when brahmins leave, brahminism remains. In practice, brahmins discriminate against Dalits and the intermediary castes (which the government categorizes as Other Backward Classes or OBCs), while OBC communities discriminate against Scheduled Caste (SC) communities. ${ }^{1}$ In contemporary times, untouchability practices are most evident in what food is consumed and how food is shared between caste communities (Thorat and Lee 2005). 
Unlike in the West, where poor women from minority groups disproportionately perform care work for families from dominant groups, in India, women from Scheduled Caste (SC) communities are more likely to be excluded from performing some types of care work, such as cooking. While members from SC communities are expected to perform cleaning jobs (Coffey and Spears 2017), they are excluded from performing care work related to cooking. Further, as this article shows, caste intersects with privatization, as $\mathrm{OBC}$ and other privileged-caste parents send their children to private schools rather than to an anganwadi that services SC children or is serviced by an SC worker. While caste is a significant factor, these status norms are amplified with poverty and SC communities tend to be disproportionately poorer (IIPS and Macro International. 2007b).

Intersectionality refers to how people's lives may be impacted by interlocking structures of gender, class, race, and in India, caste (Collins and Bilge 2016; Crenshaw 1991; Subramaniam and Krishnan 2019). Increasingly, social movement scholars have sought to include an intersectional analysis and have mostly adopted an inclusion model highlighting the specific experiences of minoritized groups (Hurwitz 2019; Terriquez, Brenes, and Lopez 2018). These studies show how social movements have or have not been inclusive of people of color in terms of the demographic and in the framing of grievances. By using intersectional frames and by giving attention to intersecting identities, social movements have built a diverse support base (Roberts and Jesudason 2013; Terriquez 2015; Terriquez, Brenes, and Lopez 2018).

Distinct from the inclusion model, I adopt a systemic approach to intersectionality that focuses on grievances embedded in structures of gender, class, and caste (Jones, Misra, and McCurley 2013). Grievances related to care work are intersectional by design and addressing these grievances requires attention to structural inequalities of gender, class, and caste (in India). Social movement scholars have examined intersectionality of struggles (Armstrong 2014; Davis 2016; Fisher, Jasny, and Dow 2018). Seemingly disparate struggles are often motivated by shared concerns about gender, race, climate, class, and war (Fisher et al. 2018). Others have argued that intersectionality of struggles takes the form of inter-sectoral organizing in which movements emphasize overlapping rather than discrete facets of people's lives, thus creating bridges of solidarity between potentially conflicting groups (Armstrong 2014). I adopt a systemic intersectionality approach and extend the literature on intersectionality of struggles by examining structural connections of gender, class, and caste within grievances. I use frame analysis that focuses on the prognosis to examine if and how social movement organizations include or exclude grievances.

\section{GRIEVANCES, FRAMES, AND INTERSECTIONALITY}

The renewed attention to grievances in social movement literature enables us to understand the relationships between social movements and intersectional inequality. While resources, political opportunities, and frames are important for social movements, grievances also matter (Hechter et al. 2016; McKane and McCammon 2018; Simmons 2014; Skotnicki 2019). Protests are more likely to emerge when grievances about structural issues coincide with incidental grievances, that is, grievances that result in unexpected hardships (Hechter et al. 2016). Similarly, the temporal, spatial, and experiential elements of people's grievances also matter in how social movements frame the grievance (Skotnicki 2019). When grievances typify suffering that is often unseen, activists may have to deploy frames that make those grievances visible (Skotnicki 2019).

Frames are "schemata of interpretation" that allow people to make sense of their life situation (Goffman 1974:21). When many people share a particular framing of the grievance, the possibility of collective action emerges (Gamson 1992; Benford 1993b). But movement participants differ in the frames they use to interpret the situation, referred to as framing contests or frame disputes (Tarrow 2011; Benford 1993a). Although framing contests typically occur between challengers and opponents (Tarrow 2011; Noakes 2000), frames may vary within the movement (McCammon 2012; Benford 1993a; Ferree 2003). Frames deployed in the movement may vary across different waves of the movement (Danaher and Crawshaw 2019), when movement leaders strategically 
adapt to opponent frames (McCammon 2012), when activists have ideological differences (Ferree 2003), and when movement organizations differ in the problems they identify, the alternative they envision, and the frames they expect to be resonant (Benford 1993a). Thus, frames are emergent and malleable depending on people's experiences, interactions, and identities, including how they experience intersectional grievances (Oliver and Johnston 2000).

Inclusion of intersectional grievances in this study refers to whether union frames include structural in-equalities of caste and gender alongside class. In doing so, there might be a danger of conflating ideology with frames (Oliver and Johnston 2000). Ideology is "any system of meaning that couples assertions and theories about the nature of social life with values and norms relevant to promoting or resisting social change" (Oliver and Johnston 2000: 43). Scholars have written extensively about gender ideology and the ideology of caste (Davis and Greenstein 2009; Dumont 1980). Thus, the exclusion of caste and gender may very well be the result of a particular caste and gender ideology of brahmanical supremacy and/or patriarchy. Overextending the use of frames may undermine the deeper socialization processes needed for ideological change (Polleta and Ho 2006; Oliver and Johnston 2000).

The presence of caste and gender can also be explained based on whether we analyze movement frames as the perimeter of a picture or as the structure of a building (Gamson 2004). As a picture frame, movement organizations may strategically emphasize some elements to the exclusion of others. Examining frames as the structure would reveal deeper ideologies that influence such interpretations (Polletta and Ho 2006). Yet, because they are more malleable and available for empirical observation, frames, as snapshots of people's thinking process at various points, may throw light on the process of ideological change if and when they happen (Snow and Benford 2005; Oliver and Johnston 2000). Examining whether intersectional frames appear in some form in the collective action frames may illuminate if and how intersectional grievances are included.

Social movements develop collective action frames with diagnostic, prognostic, and motivational elements - recognizing the cause of the grievance, identifying the solution and the target, and providing the rationale for the call to action (Benford 1993b). When considering prognostic disputes, the focus has largely been on variations in the alternative vision rather than on the target of action (Benford 1993a). Intersectional grievances such as caste and gender are durable inequalities seen across boundaries of state and society (Tilly 1999). To include those grievances, movement organizations may need to target both state and society in their collective action frames. Typically, when referring to society, scholars have treated the emergence or the ineffectiveness of frames as a feature of discursive opportunities in seemingly static cultural contexts (McCammon, Muse, Newman, and Terrell 2007; McCammon, Hewitt and Smith 2004; Ferree 2003). The substantive bias towards successful frames renders invisible emerging frames at the grassroots level that show the potential for cultural change if adopted by the movement organization.

Through a frame analysis that focuses on the grievance, I demonstrate how individuals and social movement organizations may align or differ in how grievances are framed. In particular, I examine two grievances of anganwadi workers, weakening of public provision of care and low wages. I argue that grievances are intersectional in that it is embedded in intersecting structures of gender, caste, and class. Although privatization of care is exacerbated by caste-based segregation that affects the marginalized groups the most, segregation of care based on caste impacts all anganwadi workers irrespective of their identities. An intersectional analysis enables acknowledging differences and similarities in grievances across different groups (Roberts and Jesudason 2013). By placing grievances at the center of intersectional analysis, we see how seemingly distinct concerns are structurally connected for different groups.

\section{TAMIL NADU CONTEXT}

Tamil Nadu, located in the southeastern part of India, is home to 72 million people, comparable in this regard to the United Kingdom (66 million), France (67 million), and Thailand (69 million). 
Tamil Nadu ranks among some of the high-performing states in India in addressing infant mortality rate, child malnourishment, and children's immunization rates. In terms of caste demographics, Tamil Nadu has 68\% Other Backward Class (OBC) members, 20\% Scheduled Caste (SC) members, $1 \%$ Scheduled Tribe (ST) members, and the remaining 10-11\% categorized as 'Other' referring primarily to the upper castes. Tamil Nadu has a long history of social movements including anticaste and antibrahmanical movements led by $\mathrm{OBC}$ communities, communist movements, and Dalit movements. Antibrahmanical movements in Tamil Nadu evolved into major regional political parties that have been electorally successful in the past few decades. The communist movement and the Dalit movement in Tamil Nadu also have their own political parties, which were very active at my field site. Thus, Tamil Nadu is a politically plural and vibrant movement space.

The history of antibrahmanical movements in Tamil Nadu has made the state one of the pioneers in affirmative action in India, where close to $69 \%$ positions in educational institutions and government employment are reserved for OBC, SC, and ST categories. Affirmative action is implemented in the case of anganwadi workers where jobs are reserved for women from OBC, SC, and ST categories. Besides caste, the Tamil Nadu government has policies that encourage the recruitment of women who are widows and women who do not have much family support. Despite affirmative action policies, the wealth distribution among different caste communities continues to be disproportionately in favor of higher castes (IIPS and Macro International 2007b). Moreover, even though Tamil Nadu performs relatively better in terms of human development indicators such as maternal mortality rate and women's literacy, other gender-based indicators, such as attitudes towards domestic violence, mentioned earlier, show how gender norms are deeply embedded in Tamil Nadu. Thus, the relatively better human development must be examined in the context of inequalities of gender, caste, and class in Tamil Nadu.

The Integrated Child Development Services (ICDS) is a welfare program conceived by the Indian government at the national level but implemented by the state governments on a costsharing basis. The ICDS offers a package of six services: supplementary nutrition, pre-school nonformal education, nutrition and health education, immunization, health check-ups, and referral services. The ICDS services are provided through the anganwadi, which is staffed by an anganwadi teacher and a helper. Tamil Nadu is documented as a success story with respect to the implementation of the ICDS, a service that is primarily used by women and children (Citizens' Initiative for the Rights of Children Under Six 2006; Vivek 2015). The anganwadi teachers and helpers are unionized and the workers have participated in multiple protests. At the Tamil Nadu state level, various anganwadi unions organize rallies and protests in the capital city. For this study, I focus on the charter of demands of the anganwadi union affiliated with the communist movement. At the grassroots level, individual workers and even the local union leaders were ambiguous about their political ideology. The ICDS is an ideal case to analyze intersectional grievances as the anganwadi is a space predominantly occupied by women, including women from marginalized caste communities.

\section{Privatization of Care in Tamil Nadu}

Tamil Nadu, often considered the welfare capital of India, may not seem to fit the image of a neoliberal state that privatizes care. ${ }^{2}$ However, scholars have documented policies that encourage privatization, deregulation, dispossession of land, and informalization of labor that capture the essence of neoliberalism (Vijayabaskar 2011). As corporations continued to employ informal precarious labor without offering benefits, labor movements in Tamil Nadu began to target the state for welfare benefits (Agarwala 2013). Similar focus on the state is also visible in the charter of demands of the anganwadi union.

A major part of this article examines how anganwadi workers and their union frame grievances related to privatization of care. Here I provide some context. Before independence in 1947, primary education in Tamil Nadu was governed by the Madras Elementary Education Act 1920 (later known as Tamil Nadu Elementary Education Act) which required publicly managed 
elementary schools to provide free and compulsory education to children. A major expansion in education infrastructure, introduction of noon meals at schools, and the provision of school uniforms improved the state of education in Tamil Nadu (Muthusamy 1988). However, from 1970s, things began to change as public funding for education declined and private schools began to emerge (Duraisamy 2003; Rajagopalan 2004). The privatization of schools at the elementary school level resulted in the emergence of private "nursery schools," a term used to describe preschools that provide early education for children, similar to the anganwadi.

The privatization of schools in Tamil Nadu was introduced in gradual steps. Traditionally, the school system in Tamil Nadu has had different forms of management. The government manages public schools, while private schools are aided (with some funding from the government) or unaided (recognized by the government but not government funded). Aided private schools are prohibited from charging tuition fees from students. Unaided private schools may charge tuition fees from students to cover their costs. With reducing investment in education spending, the government encouraged more self-financing private schools (Rajagopalan 2004). Currently, in Tamil Nadu, 22\% of schools are private unaided, $14 \%$ are private aided schools, and only $64 \%$ are public schools (Ponnaiah 2018). According to the Annual Study of Education Report, the number of children enrolled in private schools in rural Tamil Nadu increased to $31.9 \%$ in 2014 from 19.5\% in 2011 (ASER 2015). 46.1\% of first grade children in rural Tamil Nadu were enrolled in private schools in 2018 (ASER 2020). Unlike most public- and private-aided schools that are Tamil language, private unaided schools are primarily English-language schools.

The emergence of private English medium schools is also an indication of changing aspirations among Tamil citizens to learn English, a marketable language in a globalized world. With the growth of private English-language schools, several private and often unregulated preschools emerged to provide a pipeline of school ready students (Rajagopalan 2004). The private schools that anganwadi workers refer to are these privatized pre-schools that cater to children below six years, preparing them for elementary/primary school. In recent years, in response to fatal fire accidents and massive tuition fees, policies such as The Tamil Nadu Schools (Regulation of Collection of Fee) Act 2009, Code of Regulation for Approved Nursery and Primary Schools, and Tamil Nadu Private Schools Regulation Act 2018 were introduced to regulate private schools. These legislations are testimony to the increasing privatization of education and care in Tamil Nadu. Increasing privatization of pre-schools intersects with the caste structure to segregate children based on caste and class.

\section{DATA AND METHODS}

This article is part of a larger study that examined how state policies influence women's sense of entitlement about childcare and food from the state. Three types of data informed this study: participant observation, semistructured interviews, and archival data. I gathered data in rural Tamil Nadu from June 2016 to October 2016. Primary data for this study include (1) ethnographic notes and observations at the anganwadis, official meetings, and rallies (2) fifty semistructured interviews with anganwadi workers, mothers, anganwadi union leaders, and state representatives. (3) archival data, primarily the documented charter of demands of the anganwadi union.

Using a nonprobabilistic sampling strategy, I purposively selected two anganwadis where I conducted repeated observations and followed two anganwadi teachers as they carried out their various activities. One anganwadi serviced mostly Scheduled Caste (SC) families but was staffed by anganwadi workers who belonged to Other Backward Class (OBC) community. Although there were $\mathrm{OBC}$ families nearby, their children did not attend the anganwadi. The second center also serviced mostly SC families even though there were OBC families in the area. In the second center, the helper belonged to SC community while the teacher belonged to OBC community. Although I conducted in-depth observations at two anganwadis, I visited more than fourteen 
anganwadis to conduct interviews, allowing me to see variations in infrastructure across centers, the caste demographics, and the grievances that are general and specific to those anganwadis. Table 1: Caste Profile of Mothers and Anganwadi Workers

\begin{tabular}{lcccc}
\hline \hline & $\begin{array}{c}\text { Scheduled Caste } \\
(\text { SC) }\end{array}$ & $\begin{array}{c}\text { Other Backward } \\
\text { Class }(\text { OBC })\end{array}$ & $\begin{array}{c}\text { Upper } \\
\text { Caste }\end{array}$ & Total \\
\hline Mothers & $13(65 \%)$ & $7(35 \%)$ & - & $20(100 \%)$ \\
Anganwadi workers & $6(30 \%)$ & $13(65 \%)$ & $1(5 \%)$ & $20(100 \%)$ \\
Total & 19 & 20 & 1 & 40 \\
\hline \hline
\end{tabular}

The two anganwadis that I chose for observation were not outliers as compared to other anganwadis. But, the combinations of SC helper and $\mathrm{OBC}$ teacher in one center in a mixed-caste neighborhood and two $\mathrm{OBC}$ workers (teacher and helper) in another center in a predominantly $\mathrm{SC}$ area allowed me to examine in detail, the various ways in which caste plays out in interactions between workers and the families in the context of care work. Repeated observations at these anganwadis also acclimatized me with anganwadis and enabled more relevant observations and questions when visiting other anganwadis.

Data for this article are primarily from interviews. ${ }^{3}$ I adopted a purposive sampling strategy to select respondents across caste categories in ways that represent the actual utilization of the ICDS (IIPS and Macro International 2007a). Higher proportion of children and mothers from the SC community are likely to use the anganwadi (IIPS and Macro International 2007b). See table 1 for the caste profile of anganwadi workers and mothers I interviewed. I also interviewed union leaders and state representatives. Besides structured interviews, I had several unstructured conversations with mothers, anganwadi workers, state representatives, and union leaders. I interviewed everyone in Tamil and later translated and transcribed in English.

To examine union frames, I analyzed the union charter of demands at both the national level and subnational level (Tamil Nadu state level) of the same union so as not to miss out demands that may be specific to Tamil Nadu. The national-level charter of demands was available online (AIFAWH 2019). I collected a copy of the state-level charter of demands from the local office in Tamil Nadu. I translated the state-level copy of the charter of demands from Tamil to English.

Frame analysis often includes textual analysis of movement documents and transcripts of interviews with activists (Johnston 2002). To examine variations in frames deployed by workers and union leaders, I utilized NVivo to open-code the transcripts of the interviews and then combine codes that were thematically aligned (Charmaz 1983). Although many of my interview questions were designed to discuss issues related to the union, I did not expect these specific findings before my fieldwork. However, some of these themes had begun to emerge as I wrote regular memos during my fieldwork. Scholars who use interview data for frame analysis have examined how often activists and participants refer to a particular frame (Johnston and AarelaidTart 2000). Thematic codes that were most relevant to this article were "private schools," "children don't come," "caste," "comparing work," "belief in struggle union," and codes related to salary/wages. All these codes were seen frequently across various transcripts. Comparison diagrams and matrix coding in NVivo allowed me to see how often these codes overlap in transcripts of interviews. The overlaps between codes "caste" and "private schools" as well as "comparing work" and "salary" are evident in these diagrams. This article aims to develop a conceptual explanation rather than generalize to a population. To create a conceptual argument, I mapped these codes to diagnostic and prognostic elements of frames and compared them with union frames to distinguish variations in targets.

Although it is important to examine how often particular themes emerge in interviews, delineating grievances required a more holistic approach. Caste is a very sensitive topic. Several variables influence if and how an anganwadi worker refers to caste. For example, some workers from $\mathrm{SC}$ community in leadership roles would refer to caste as an injustice while $\mathrm{OBC}$ workers would refer to caste as a reality of their lives. Rapport also mattered. Workers and mothers from SC community did not always want to refer to themselves as victims of caste-based discrimination, 
especially to someone they perceived to be an outsider to their community. ${ }^{4}$ With repeated visits, some mothers in SC neighborhoods would imply that they were discriminated against, without mentioning caste. Interviewing helpers, mothers, and teachers in the same center allowed me to triangulate my observations related to caste. For example, in some cases, the SC worker may not refer to her personal experience of caste-based discrimination, but the $\mathrm{OBC}$ worker in the center would inform me how people discriminated against the SC worker. People's behavior, experiences, and verbal accounts may differ and therefore, a combination of semistructured interviews and observations allowed me to confirm or disconfirm themes that emerged in interviews (Jerolmack and Khan 2017). As someone with knowledge about Tamil society, I am also culturally aware of the various ways in which caste is coded. For example, a teacher from the OBC community passed me a bottle of water with the suggestion "don't drink water from there," as I got ready to walk to an "SC street," to speak to mothers. Thus, ethnographic observations were key to deriving insights on caste about which people were more reticent in interviews. Although caste as an important factor in segregation was very evident, who spoke about it in interviews may be influenced by their specific identities, anticaste consciousness, and whether they trusted me.

\section{FINDINGS}

I utilize a systemic intersectional approach to examine how grievances such as low wages and weakening of public provision of care compared to the documented charter of demands of the union. I find that individual anganwadi workers use frames that draw from their intersectional lived experiences. The union rarely referred to how grievances were impacted by structures of gender and caste. Although the union frames differed from that of individual workers, their prognosis matched in the case of the wage grievance. Both the union and the individual workers identified the state as the target for action to increase their wages. In the case of weakening of public provision of care, individual workers interpreted the grievance as caste intersecting with privatization of care. Thus, according to individual workers, the target for action was not just the state, but also society. In contrast, the union identified privatization as a state problem.

\section{Low Wages}

The demand for better wages and benefits was the most prominent demand among individual workers and in the charter of demands. However, there were variations in how individual workers interpreted their grievance regarding wages.

\section{Individual Frame: Unwaged Time, Unequal Wages}

In her essay on wages for housework, Silvia Federici (2012:16) describes how housework is devalued by ascribing women with a natural gift for caring. She writes, "Housework was transformed into a natural attribute, rather than being recognized as work, because it was destined to be unwaged." Although Federici's argument is about unpaid work done by women at home, the belief that women are naturally inclined to care has often meant lower wages for care workers (England 2005), and justified the demand for unpaid work even in the context of paid care work.

The ICDS recruits only women as anganwadi workers. Although the website or the application form does not specify marital status or motherhood as criteria for recruitment, anganwadi teachers and ICDS officers reported that women who are/were married and with children are preferred. ICDS officers referred to "patience and maturity" in mothers, making them ideal candidates to be anganwadi workers. While the policy has provided job opportunities to many women, the anganwadi workers referred to how their work is devalued.

The Tamil Nadu government promises to provide full-time childcare from 9 am to $3 \mathrm{pm}$ from Monday to Saturday, a much-needed service for mothers in the community. Yet, the government treats anganwadi workers as voluntary or honorary workers expected to work for 6 hours and 
more (Palriwala and Neetha 2010). Even though they are paid a salary, as honorary workers, anganwadi teachers and helpers do not have the same benefits and wages as full time permanent government employees who may be doing similar work. In referring to their demand for higher wages, individual anganwadi workers articulated their grievance in three ways: unwaged time, unequal wages when comparing their jobs to job categories that included men, and unwaged miscellaneous tasks.

Anganwadi teachers and union leaders referred to the time they spent at work while being labeled as part-time workers. As union leader Malliga told me,

The government says our work time is from 8:30 am in the morning to $4 \mathrm{pm}$ in the evening. How can this be part-time work? After doing all this work and with this timing, is it fair to call us part time workers? . . Either fix our time or fix our salary.

Thus, anganwadi workers interpreted their grievance as unwaged time. They emphasized their unwaged time by comparing their wages (around Rs. 9,000 to 10,000) to wages in jobs that also recruited men. For example, an anganwadi worker, Gouri, compared her salary to that of teachers in schools, a job category that recruits men.

First grade teacher makes Rs. 35000 . Sometimes they only have five children. Sometimes ten to fifteen children. . . . We maintain registers, we visit the area, we do house visit and whatever is required of us. In my opinion, we should get more salary than we do now.

A union leader and a retired anganwadi worker, Banu, in the capital city of Chennai compared their work to clerical jobs in government offices, another job that recruits men. She demands that anganwadi workers be paid the same as a junior assistant, whose wages are based on the time spent in office.

Say you want to recruit a junior assistant at the office. That position requires a tenth grade education. Anganwadi teachers have all passed tenth grade. So, we should get the same salary as the junior assistant. .. . Junior assistants work in an office. They all go to office on time. They are in office till evening. It is about time for them. . . They give us low salary and ask us to do all this work.

Anganwadi workers also referred to the practice of requiring workers to perform miscellaneous tasks beyond caring for and teaching children. As the anganwadi is one of the most local arms of the government, anganwadi teachers were often used for other government programs. Anganwadi workers reported how they were involved in organizing various health initiatives without fair pay while neglecting the job they were hired for. Many anganwadi workers demonstrate pride in the role they played in eradicating polio, popularizing immunization, and reducing malnourishment. India was declared free of polio in 2014. Tamil Nadu ranks first among all states in child immunization (IIPS and ICF 2017). For anganwadi workers, the satisfaction of going the "extra mile" for their community co-existed with frustration at how those jobs blur the boundaries of their job description. As the union leader Elizabeth says,

We have eradicated polio. Don't we have a huge contribution in ensuring that not a single child has polio? Vaccination ... population survey ... increase in voter registration . . . adolescent girls program ... We have made them all successful. But none of this is our work. But the government has made us do all this.

For Elizabeth, expecting anganwadi workers to perform jobs outside of the ICDS is an example of how the boundaries of work kept expanding even as they are paid less. I also personally witnessed how teachers spent time (during and outside of working hours) for events related to affiliated government programs. Thus, workers interpreted their grievance of low wages as a gendered phenomenon of unwaged time, unequal wages, and unwaged work.

\section{Union Frame}


To analyze the union's frame, I examine the stated demands in the union's charter of demands both at the national level and at the Tamil Nadu state level. The union's national level charter of demands had forty-four demands while the state level charter of demands had twenty-eight demands. In the union's national level charter of demands, the union refers to the grievance related to wages in the following manner:

- Regularize all anganwadi workers as Grade III and helpers as Grade IV government employees.

- Minimum wages of skilled workers to the tune of Rs. 30,000 should be paid to anganwadi workers and that of semiskilled workers to the tune of Rs. 21,000 to helpers. Remuneration of anganwadi employees should be linked up with consumer price index.

The Tamil Nadu state-level union charter of demands includes the following demands:

- Anganwadi workers and helpers who have been working for thirty-two years must be made into full time permanent workers with benefits provided on a regular basis.

- Since workers in Tamil Nadu work for four hours more than what is required in other states, they should be offered federal/central government salaries.

- Anganwadi workers should be exempted from work outside of ICDS work. When utilized for other jobs, officers should compensate workers accordingly.

The national-level union demands regarding wages were framed in relation to job categories, increments, and cost of living. They argue for upgrading job categories (and therefore salaries and benefits) of anganwadi teachers to skilled workers and anganwadi helpers to semiskilled government employees. The state-level charter argues for workers (who have worked for thirty-two years) to be considered as permanent employees. Framing their grievance as an issue of job categories alone obscures the gendered ways that different job categories are differently valued and paid. The Tamil Nadu charter of demands refers to the extra four hours that anganwadi workers in Tamil Nadu put in compared to anganwadi workers in other states but not in comparison to other jobs that recruited men. However, the Tamil Nadu charter of demands does include the grievance regarding miscellaneous tasks that resulted in blurred job descriptions that expanded care work. Thus, the Tamil Nadu state charter included some aspects of the framing of anganwadi workers but not all.

Anganwadi workers rarely referred to gender inequality directly, but they referred to the gendered phenomena of unwaged work, unwaged time, and unequal wages, especially compared to other government jobs that recruited men. The Tamil Nadu union demands include the grievance of unwaged work but did not frame their grievances as unwaged time or unequal wages between their jobs and those that traditionally included men. Even though there were slight differences in framing between workers and the documented charter of demands, anganwadi workers acknowledged the union as critical for securing wage increases. For example, Mohana, an anganwadi worker told me, "If our salary is Rs. 9000 to 10000 now, it is because of our protests. We protested year after year and got one thing after the other. That is how our salaries increased."

Thus, workers believed that the union represented their grievance regarding wages and saw themselves as part of the struggle. Moreover, irrespective of the slight variations in frames, the prognostic aspects of their frames are similar - that the state must pay higher wages.

\section{Challenges in Deploying Gender Equality Frame}

Although workers articulated the gendered phenomenon of devaluing their care work, workers also did not refer to gender. Some union leaders were aware of the gender wage gap. Yet, their statements demonstrated the complexities in framing intersectional grievances within a social movement. Elizabeth, a union leader refers to the challenges of comparing jobs while ensuring solidarity between all workers.

Organizers of noon meals in schools and anganwadi teachers receive the same salary. Noon meal 
organizers come at $10 \mathrm{am}$ and leave at $2 \mathrm{pm}$. They can be men as well. They need to run the family. This salary is not enough. But we the anganwadi workers feed children and teach them. We do more work than them. If those who take care of three registers in the noon meal program get this much salary, what about me, a teacher in the anganwadi? They should pay us more. But the government says that we shouldn't talk about their salary. Are we asking the government to reduce their salary? No. By saying that, the government is attacking our solidarity.

Anganwadi union leaders who work with men union leaders often emphasized solidarity rather than gender inequality between workers. In many districts in Tamil Nadu, noon-meal union leaders are men. Protests for salary increases often included both noon-meal workers and anganwadi workers. Anganwadi union leaders recognized the power of solidarity in numbers.

Further, they find that the Tamil Nadu government exploits women's empowerment to temper their struggles. For example, the Tamil Nadu government gives preference to "widows and destitute women" while recruiting anganwadi workers. Widows are extremely stigmatized in rural Tamil Nadu. They are seen as bad omen and often excluded from various celebrations. Many workers appreciate the Tamil Nadu government's policy to recruit widows. Anganwadi workers who are widows told me that their job has elevated their life circumstances in income and status. Yet, the union leaders recognize how bureaucrats exploit the intersection of gender and poverty to weaken their struggle.

Elizabeth: Because we are women, they'll find different ways to repress our strikes. An officer might say, "We will suspend people who go to the strike. Jaya, don't listen to Baby. If Baby loses her job, she'll be fine. You don't have a husband or children. Say yes to them, but come to work anyway." There are many widows among anganwadi workers. They'll believe that.

Author: But they have jobs now. That is good for women, isn't it?

Elizabeth: Yes, they have jobs. Correct. But when we call them for protests for demanding salary increases, what happens when officers threaten these women?

Thus, gender is a frame that union leaders identify as being vulnerable to attacks from the state as they struggle for higher wages. Even as union leaders identify gender inequality in how their work is valued, both union leaders and workers referred to gender only in subtle ways. Even though gender inequality is also a societal problem, workers and the union interpreted low wages as a state problem and demanded that the state increase their wages. Such alignment did not happen in the case of the second grievance, weakening of public provision of care.

\section{Weakening the Public Provision of Care-The Children Don't Come}

Earlier in the article, I described how education and childcare in Tamil Nadu was becoming increasingly privatized. As private pre-schools increase in numbers especially in the context of caste-based segregation, many anganwadi workers referred to how the number of children coming to the anganwadi had reduced because of caste and class based segregation.

\section{Individual Frame-Caste and Privatization}

In India, caste plays a major role in how resources are distributed in society, including in state provided welfare services. Families from Scheduled Caste (SC) communities are often discriminated against by members of other castes. In the case of the anganwadi, some people from uppercaste and Other Backward Class (OBC) communities may choose to not send their children to an anganwadi located in an SC neighborhood or to an anganwadi where the teacher or helper belongs to the SC community. While caste boundaries have blurred in some places, caste-based segregation continues. Segregation based on caste sustains the caste structure and weakens the anganwadi system which impacts poor people from all caste communities. An officer from the ICDS system narrates the challenges of recruiting children to the anganwadi. 
We have severe caste problems. ... OBC people will not send their children to the SC area center because they think their children will have to mingle with SC students. When an anganwadi worker tells me "Madam, there is a caste problem. People are not sending their children. What can I do?" I cannot tell them anything. . . . We have all the facilities - fans, toilet, water, and play area! But still, they do not send their children because it is in the SC area.

Anganwadi workers also corroborated the officer's observation and described untouchability practices in the community. Excerpts from an interview with Jothi, an anganwadi helper from the SC community demonstrate how caste mediates her experience as a worker in an anganwadi that serves SC and OBC children. When I asked, “Why don't the children come?” Jothi replied,

For example, there is a woman and daughter who live close by. When I go to get the child, the mother doesn't let her come. If I say, at least give the egg to your child, she will come for the egg but will take the child back with her.

Both Jothi and the teacher managing her anganwadi are from the SC community. People from OBC communities take raw eggs but not the food cooked by the helper from the SC community. The teacher told me that OBC people would throw the cooked food away even if they take it from her. They also do not bring their children to the center even though they come for the eggs. Why OBC people take raw eggs but not the cooked rice is testimony to the arbitrary nature of how caste is constructed. Untouchability practices are especially pronounced in the case of food as they consider food cooked by SC people as "impure." Jothi's grievances are based on caste, but the union seldom engages with the issue.

\section{Caste Intersects with Privatization}

The government is legally accountable to provide ICDS services to all children under the age of six (Krishnan and Subramaniam 2014; Dréze and Khera 2017). Yet, increasing privatization has weakened the public provision of care by exacerbating caste and class. In particular, families from upper caste and $\mathrm{OBC}$ communities tend to not send their children to anganwadis located in Scheduled Caste (SC) neighborhoods. Instead they send their children to private schools that are often not accessible to poor communities, predominantly SC families. While some economically mobile SC families also send their children to private pre-schools, it was not common.

For anganwadi workers, the competition from private pre-schools impacts the number of children that use their services. The caste structure further amplifies the problem. Privatization did not create the caste structure, but it has exacerbated caste-based segregation in the areas I visited. Vijaya's anganwadi is located in an SC neighborhood and OBC families do not send their children to the center. Vijaya describes to me how OBC families referred to "choice" as they justified caste-based segregation.

They won't let their children come because the anganwadi is in an SC area. . . There are two private schools nearby. . . . In our office, they say we should persuade parents to come here. But we cannot force them. It is their wish. This year, two OBC families told me that they are going to send their kids to the private school. I asked them, "Why are you sending them there? We offer free service." But they say, "I have one child and I want to send him there."

Thus, the presence of private schools further exacerbated caste-based segregation. In this case, Vijaya and the helper are from the OBC community but OBC families do not send their children to the anganwadi because they do not want their children to go to the SC area. Thus, workers identified caste as intersecting with privatization.

At a training program for anganwadi workers, many anganwadi workers referred to how they find it difficult to recruit children in a context where non-SC and economically mobile families (including from SC families) preferred to use private schools rather than send their children to the anganwadi. The surge in the number of private pre-schools not only affects poor families from the SC community, it also impacts anganwadi workers from all caste communities whose jobs 
are precarious as they try to recruit children. For example, helper Krishnaveni told me that she has applied for a transfer to another anganwadi as the reducing number of children in her center, made her feel precarious.

Out of the fifteen children registered, around six children come. Today, only one child has come.

... I know that my job is at hazard. There are more children in the other center. The number of

children will not reduce there. . . That is an SC area. I have requested for a transfer to that area.

Krishnaveni's anganwadi also faces severe competition from private schools. In Tamil Nadu, higher proportion of children from SC communities utilize the services of the anganwadi (IIPS and ICF 2017). That very few upper caste children use the anganwadi has more to do with segregation than access. When the number of children reduce, the relevance of the ICDS and the jobs of the anganwadi workers are vulnerable, an intersectional grievance that affects all workers. Thus, privatization intersects with caste-based segregation in ways that affect workers irrespective of their caste identities.

\section{Union's Framing of Privatization}

Although privatization is an important issue for the union in the charter of demands, it was not linked to caste. Challenging the privatization of ICDS is the first demand in the union's charter of demands at the national level. It states, "Stop privatization of ICDS in any form in the name of Public Private Partnership or restructuring." By privatization, the union refers to the increasing NGOization of the ICDS. The Indian government has increasingly transferred ICDS management to non-profit organizations, many of whom are aligned with corporations. The union's current focus at the national level is to protest the privatization of ICDS through corporate intervention. The most recent charter of demands from the conference held in November 2019 includes a demand about regulating pre-schools, but it does not refer to private preschools. The union's demand is to differentiate anganwadis from public preschools.

Given that private preschools might be phenomena more prevalent in Tamil Nadu, it is useful to evaluate if the Tamil Nadu branch of the union includes a demand regarding private schools. The ninth demand out of twenty-eight demands in the Tamil Nadu charter of demands says:

To increase the number of children coming to the center, the Tamil Nadu government should withdraw permissions given to private schools. The Tamil Nadu government should release an order that requires children at 5 years to secure a certificate from anganwadi workers before joining primary school.

Thus, the Tamil Nadu state union includes a demand that requires the state to withdraw private school permissions. Most workers referred to how the number of children coming to the anganwadi had reduced because of increasing privatization as well-off families chose to send their children to private schools. While some upwardly mobile SC families also sent their children to private schools, it was usually non-SC families that chose private schools. But even the state charter of demands did not mention caste anywhere. Instead, both the national and the state union charter of demands argue for a certificate from the anganwadi as a pre-requisite for admission to the primary school. The demand to get a certificate from the anganwadi seems to be borrowing the frame of expertise that private schools often adopt.

\section{Challenges of Deploying Anticaste Frame}

Despite caste being a recurrent theme in how anganwadi workers interpreted why people do not send their children, the union's charter of demands did not mention caste. Although the larger communist trade union that the anganwadi union is affiliated with, has initiatives to address untouchability practices, demanding change from members of the society as a prognostic frame was not visible in the anganwadi union's charter of demands. Unlike the demand for higher wages, there was no match between the prognostic elements of the individual workers' frames and the union frames. The challenges of including intersectional frames is also visible here. 
Although the intersecting grievance of caste and privatization affects both $\mathrm{OBC}$ and SC workers in recruiting children, some workers belonging to $\mathrm{OBC}$ communities may themselves practice untouchability. My interview with Malathi, an anganwadi teacher from the SC community, was insightful in this regard. Malathi was elected to represent the workers in her block, the most local section of workers. It was not easy for Malathi to get elected in her block given her caste status. To my question of whether they have raised the issue of caste-based discrimination in the union, Malathi answered thus:

No. We won't ask in the union. We just have to face it by ourselves. . . Even in our office, do you know how many people were jealous that other teachers nominated me as the leader? They ask, "Aren't there any OBC people here?" ... Even the teacher who used to work in this center discriminates against SC people. If the helper, [from the SC community] gives water, the teacher wouldn't drink it. She is a teacher!

The above quote from Malathi emphasizes the challenges in addressing caste-based issues. On one hand, SC and OBC workers identify society as the target for change, while the union only targets the state. At the same time, 'society' includes OBC anganwadi workers who may themselves need to change. Moreover, some union leaders in the larger labor movement frame caste-based discrimination as separate from workers' rights. Here is an excerpt from an interview with Sumathi, a union leader associated with the larger trade union:

Author: Does the union deal with caste-based issues in relation to the anganwadi?

Sumathi: Not that I know of. I have interacted with the anganwadi union for fifteen years but these issues have not come up. But we have to find out if that is the case.

Author: Does the labor struggle speak about caste?

Sumathi: That we do speak. In our national conference, when we speak about social issues, we specifically speak about Dalits and their issues.... We should fight untouchability.

Thus, some leaders do not see caste-based discrimination as an issue that intersects with carework and privatization. Rather, they see it as a separate grievance. These findings highlight three challenges in including intersectional grievances in the union charter of demands: First, castebased discrimination continues to be a concern even between workers, where workers of non-SC communities discriminate against those from SC communities. Second, the union has not yet articulated caste-based discrimination as a grievance that intersects with the privatization of care work in particular or with care work in general. Third, the union charter of demands is directed towards the state. When individual workers discuss privatization, they identify privatization intersecting with caste-based discrimination, a societal problem. However, the union charter of demands frame privatization as a state problem.

Whether the exclusion of caste is an issue of prognosis or ideology needs to be evaluated further. Some non-SC union leaders seem to acknowledge caste-based discrimination but frame it as an issue separate from labor. Other union leaders, especially from SC communities, recognize caste as an issue that affects the anganwadi operations. Yet, caste did not figure in the union's charter of demands. However, national level union leaders of the anganwadi are increasingly using the language of intersectionality. In a public speech for the International Labor Day in 2020, the national general secretary of the anganwadi workers union, responded to a question on caste and identity in this manner.

There is no short cut. You have to be with the people. You have to make them feel that, yes, this is our union. You can observe Ambedkar Jayanti day but when a fellow comrade, a Dalit, is being attacked . . . and if the trade union is not there, there is no point... You have to be with the most oppressed .... We cannot bifurcate social issues and class issues. It is interlinked. We have to declass and de-caste ourselves.

In this quote, the national anganwadi union leader identifies that the trade union may need to target the state and society. She recognizes that caste is a societal problem that may require change 
even from the members themselves, as she calls for members to "de-caste" themselves. Although the charter of demands does not yet reflect caste, leaders seem to be increasingly adopting intersectional frames. Yet, the charter of demands communicates to the public the grievances that the union will fight for. Ideological change often requires deeper socialization processes (Oliver and Johnston 2000). Frames allow us to investigate whether those changes are happening over time.

Although the union did not refer to caste in privatization, some changes are evident in the union's frames. In an earlier version of the national union's charter of demands retrieved in 2016, there was no mention of caste at all. In 2019, caste had made its way into the national charter. In 2019 charter of demands, the union demanded that the state should not ban food items such as eggs, garlic, and onion in the anganwadi menu in the name of caste and religion. In some parts of India, upper-caste groups have used their privilege to lobby for removing eggs from anganwadi meals in compliance with upper-caste food preferences, even though Dalits and OBC communities consume eggs. In other states, nonprofit organizations that manage anganwadis have removed eggs from the menu irrespective of the dietary preferences of their SC and $\mathrm{OBC}$ users. In demanding that the state should not restrict the menu based on caste preferences, the union acknowledges the power wielded by upper caste groups in society, even as it targets the state, in terms of prognosis.

This article does not argue that inclusion of intersectional grievances may result in successful outcomes for the union. The union may well have made the strategic choice to target the state. However, given how grievances related to care work are inherently intersectional, a trade union of care workers does have the opportunity to develop intersectional frames. In doing so, as the national anganwadi union leader says, the most oppressed people may feel like "this union is for them."

\section{DISCUSSION: INTERSECTIONALITY OF GRIEVANCES}

This article utilizes a systemic intersectional approach to examine grievances as intersectional. I particularly examine how individual workers and the union's charter of demands frame two specific grievances- - low wages and weakening of public provision of care. In discussing these grievances, workers utilize frames that highlight the devaluation of care work in the form of low wages and caste discrimination that exacerbates privatization of care. Thus, workers demonstrate how care is inherently intersectional. Given how intersectional grievances traverse the boundaries of state and society, this article argues that the prognostic aspect of movement frames may also need to be examined to ensure the inclusion of intersectional grievances.

In the case of low wages, even though the union's frames did not directly compare anganwadi jobs (done only by women) to other jobs (that included men) as individual workers did, their prognosis was in alignment - target the state to provide higher wages. Most individual workers acknowledged the union's role in securing higher wages for them. While the union's charter of demands was inclusive of the privatization grievance, it did not refer to caste-based segregation. Individual anganwadi workers recognized that privatization of care intersects with caste in ways that makes recruitment of children, especially non-SC children, more difficult. As a result, many anganwadi workers, irrespective of caste, feel vulnerable regarding their jobs. Further, SC workers and children were discriminated against by $\mathrm{OBC}$ parents. While individual workers see privatization as a societal problem, the union's frame targets the state to address privatization of care. Thus, the union and individual workers did not share the prognostic elements of the frame regarding privatization.

This article contributes to literature on social movements and inequality in three ways. One, I join other scholars to bring attention back to grievances as critical to our understanding of social movement mobilizing. I adopt a systemic intersectional approach to examine grievances not only in terms of who is affected but how grievances are embedded in intersecting structures of gender, caste, and class. Grievances related to care are especially suited for intersectional analysis given how social relations of gender, caste, and class impact how care is distributed and valued in society. Examining grievances as intersectional allows us to examine structural connections of 
gender, class, and caste within grievances. Moreover, we see how seemingly distinct concerns are structurally connected for different groups even as marginalized groups are disproportionally impacted. This insight may help social movements frame their grievances in ways that center marginalized groups while acknowledging the broader impacts of those grievances.

The second theoretical contribution is to emphasize an element of framing that is not given much attention in social movement literature-prognosis. Prognosis, or the part of the frame that identifies the target and the solution for the grievance is often subsumed within the larger frame. This article demonstrates how the union's singular focus on the state as the target may have precluded the possibility of challenging caste. This was not always the case in Tamil Nadu because, historically, the communist labor movement was led by Dalit agricultural laborers who were engaged in militant labor struggles against land-owning caste members (Sivaraman 2013). These struggles have centered intersections of caste and class in society. However, the neoliberal trend of informalization of labor through large corporations has resulted in social movements increasingly targeting the state for welfare benefits not provided by employers (Agarwala 2013; Vijayabaskar 2011). Targeting the state may then be a strategic choice for unions, but it does exclude some intersectional grievances that travel across boundaries of state and society (Tilly 1998).

The third theoretical contribution is that it moves away from the typical focus on successful movements, that renders unrecognized grievances invisible. By focusing on protests and other successful mobilizations, we tend to disregard frames that may not align with discursive power structures (Ferree 2003). The absence of cultural resonance is often understood to be a deterrent to success. In this article, frames related to gender and caste may not necessarily align with the dominant cultural narrative. Yet, people deployed those frames. The analysis of seemingly invisible frames at the grassroots level challenge the notion of a static culture. Rather, variations in frames demonstrate the possibility for ideological change over time (Oliver and Johnston 2000). Incorporating intersectional frames deployed by individuals may enable social movements to broaden and diversify their strategies for addressing inequality.

Overall, this article focuses on how struggles related to care offer movements the opportunity to include intersectional grievances. How care is distributed in society is an indication of how social relations are structured. We cannot address grievances related to care without paying attention to intersecting inequalities of gender, caste, race and class. While demanding better care and more value for care work, a trade union of care workers has the potential to challenge power structures that oppress minoritized groups disproportionally while affecting many others. It is through such challenges that movements can claim to fight for the most oppressed among us.

\section{ENDNOTES}

\footnotetext{
${ }^{1}$ While brahmins discriminate against both Dalits and OBCs, only Dalits experience untouchability from both brahmins and OBCs.

2 Tamil Nadu as the "welfare capital" may evoke varied responses. Even under British rule, anti-brahmanical movement demands and actions resulted in welfare policies, affirmative action policies, and anti-discrimination policies. In contemporary Tamil Nadu, the competitive electoral environment between two major electoral parties (which emerged from the anti-brahmanical movement) has resulted in a combination of policies: populist policies targeting voters such as the mass distribution of electric gadgets, televisions, laptops, and food, and structural policies such as affirmative action (Wyatt 2013). Communist union leaders argue that such populist policies while providing immediate relief, often temper the revolutionary fervor of the poor as these policies co-exist with anti-poor policies. ${ }^{3}$ All names in this article are pseudonyms

${ }^{4}$ Caste as a category of stratification is significant to my positionality as a researcher. In my experience, people have often mis-identified me as a brahmin especially when they interact with me in the context of higher education. In my field site, I corrected that perception or proactively indicated my non-brahmin caste by referring to my non-vegetarian diet. Dalits rarely asked my caste, but always knew that I was not a Dalit. Dalits were less likely to share with me their personal experiences of caste-based discrimination. Even when referring to bad experiences, they rarely mentioned caste. This may be due to my outsider caste status. Dalit union leaders were vocal about caste-based discrimination. Workers from $\mathrm{OBC}$ community sometimes asked my caste, but since my caste name is not well
} 
known in the area, they could not place my caste in the hierarchy, which I believe led to an ambiguous perception of my caste status, the way I prefer it to be. When asked explicitly (which was rare), I mentioned the government category of my caste. OBC workers were open about discriminatory practices against Dalits (from parents and themselves). This openness may be due to their perception of my caste as non-Dalit. Besides caste, I believe that as a woman I had access to intimate, mixed-caste friendship networks of anganwadi workers that allowed for deep insights into various aspects of their lives.

\section{REFERENCES}

Agarwala, Rina. 2013. Informal Labor, Formal Politics, and Dignified Discontent in India. Cambridge: Cambridge University Press.

AIFAWH. 2019. Charter of Demands. Retrieved May 4, 2020 (http://aifawh.org/charter-of-demands).

Ambedkar, Bhimrao Ramji. 1917. Castes in India: Their Mechanism, Genesis and Development. Retrieved March 23, 2019

(http://www.columbia.edu/itc/mealac/pritchett/00ambedkar/txt_ambedkar_castes.html)

Armstrong, Elisabeth. 2014. Gender and Neoliberalism: The All India Democratic Women's Association and Globalization Politics. New York: Routledge.

ASER. 2015. Trends over Time: 2006-2014: Supplement to ASER 2014. Retrieved May 25, 2020 (http://img.asercentre.org/docs/Publications/ASERReports/ASERTOT/fullasertrendsovertimereport.p df).

ASER. 2020. ASER 2018-Rural Annual Status of Education Report (Rural) 'Young Children.' Retrieved May 25, 2020 (http://img.asercentre.org/docs/ASER2019/ ASER2019 report /aser2018youngchildren.pdf).

Benford, Robert D. 1993a. "Frame Disputes within the Nuclear Disarmament Movement." Social Forces 71(3):677-701.

. 1993b. "'You Could Be the Hundredth Monkey': Collective Action Frames and Vocabularies of Motive within the Nuclear Disarmament Movement." The Sociological Quarterly 34(2):195-216.

Benford, Robert D. and David A. Snow. 2000. "Framing Processes and Social Movements: An Overview and Assessment." Annual Review of Sociology 26(1):611-639.

Bhattacharya, Tithi. 2017. Social Reproduction Theory Remapping Class, Recentering Oppression. London: Pluto Press.

Boeckmann, Irene, Joya Misra, and Michelle J. Budig. 2015. "Cultural and Institutional Factors Shaping Mothers' Employment and Working Hours in Postindustrial Countries.” Social Forces 93(4):1301-33

Charmaz, Kathy. 1983. "The Grounded Theory Method: An Explication and Interpretation." Pp.109-28 in Contemporary Field Research: A Collection of Readings, edited by Robert M. Emerson. Boston: Little, Brown and Company.

Citizens' Initiative for the Rights of Children Under Six. 2006. Focus on Children Under Six. Retrieved March 23, 2019 (http://www.righttofoodindia.org/data/rtf06focusreportabridged.pdf).

Coffey, Diane and Dean Spears. 2017. Where India Goes: Abandoned Toilets, Stunted Development and the Costs of Caste. Noida, India: Harper Collins India.

Collins, Patricia Hill, and Sirma Bilge. 2016. Intersectionality. Cambridge: Polity.

Correll, Shelley J., Stephen Benard, and In Paik. 2007. "Getting a Job: Is There a Motherhood Penalty?" American Journal of Sociology 112(5):1297-1338.

Crenshaw, Kimberlé. 1991. "Mapping the Margins: Intersectionality, Identity Politics, and Violence against Women of Color." Stanford Law Review 43(6):1241-99.

Danaher, William F. and Trisha Crawshaw. 2019. "“As We Come Marching': Framing Amplification and Transformation Through Songs and Poetry." Pp. 63-86 in Bringing Down Divides (Research in Social Movements, Conflicts and Change) edited by Lisa Leitz and EitanY. Alimi. Vol. 43. Bingham UK: Emerald Publishing Limited.

Davis, Angela. 2016. Freedom Is a Constant Struggle: Ferguson, Palestine, and the Foundations of a Movement. Chicago, Illinois: Haymarket Books.

Davis, Shannon N., and Theodore N. Greenstein. 2009. "Gender Ideology: Components, Predictors, and Consequences.” Annual Review of Sociology 35:87-105.

Drèze, Jean, and Reetika Khera. 2017. "Recent Social Security Initiatives in India." World Development 98: 555-572.

Dumont, Louis. 1980. Homo Hierarchicus: The Caste system and its Implications. Chicago and London: University of Chicago Press.

Duraisamy, Malathy. 2003. "Cost, Quality and Outcomes of Primary Schooling in Rural Tamil Nadu: Does 
School Management Matter?” Pp. 177-188 in Management of School Education in India, edited by Neelam Sood. New Delhi: APH Publishing Corporation.

England, Paula, Michelle Budig, and Nancy Folbre. 2002. "Wages of Virtue: The Relative Pay of Care Work." Social Problems 49(4):455-473.

England, Paula. 2005. "Emerging Theories of Care-work.” Annual Review of Sociology. 31:381-99.

Federici, Silvia. 2012. Revolution at Point Zero: Housework, Reproduction, and Feminist Struggle. Michigan: PM Press.

Ferree, Myra Marx. 2003. "Resonance and Radicalism: Feminist Framing in the Abortion Debates of the United States and Germany.” American Journal of Sociology 109(2):304-44.

Fisher, Dana R., Dawn M. Dow, and Rashawn Ray. 2017. "Intersectionality Takes It to the Streets: Mobilizing across Diverse Interests for the Women's March.” Science Advances 3(9): eaao1390.

Fisher, Dana R., Lorien Jasny, and Dawn M. Dow. 2018. "Why Are We Here? Patterns of Intersectional Motivations across the Resistance." Mobilization: An International Quarterly 23(4):451-68.

Gamson, William A. 1992. "The Social Psychology of Collective Action.” Pp. 53-76 in Frontiers in Social Movement Theory edited by Aldon D. Morris and Carol McClurg Mueller. New Haven: Yale University Press.

Gamson, William A. 2004. "Bystanders, Public Opinion, and the Media." Pp. 242-261 in The Blackwell Companion to Social Movements, edited by David A. Snow, Sarah A. Soule, and Hanspeter Kriesi. MA: Blackwell Publishing

Goffman, Erving. 1974. Frame Analysis: An Essay on the Organization of Experience. Cambridge, MA: Harvard University Press.

Hechter, Michael, Steven Pfaff, and Patrick Underwood. 2016. "Grievances and the Genesis of Rebellion: Mutiny in the Royal Navy, 1740 to 1820.” American Sociological Review 81(1):165-189.

Hurwitz, Heather McKee. 2019. "Gender and Race in the Occupy Movement: Relational Leadership and Discriminatory Resistance." Mobilization: An International Quarterly 24(2):157-76.

IIPS (International Institute for Population Sciences) and ICF. 2017. National Family Health Survey (NFHS4), India, 2015-16: Tamil Nadu. Mumbai: IIPS.

IIPS and Macro International. 2007a. National Family Health Survey (NFHS-3), 2005-06: India: Volume I. Mumbai: IIPS.

IIPS and Macro International. 2007b. National Family Health Survey (NFHS-3), India, 2005-06: Tamil Nadu. Mumbai:IIPS.

Jerolmack, Colin and Shamus Khan. 2017. "Introduction: An Analytic Approach to Ethnography.” Pp. xixxx in Approaches to Ethnography: Analysis and Representation in Participant Observation, edited by Colin Jerolmack and Shamus Khan. New York: Oxford University Press.

Johnston, Hank. 2002. "Verification and Proof in Frame and Discourse Analysis." Pp. 92-117 in Methods of Social Movement Research, edited by Bert Klandermans and Suzanne Staggenborg. Minneapolis: University of Minnesota Press.

Johnston, Hank and Ailie Aarelaid-Tart. 2000. "Generations, Microcohorts and Long-Term Mobilization: The Estonian National Movement 1940-1991.” Sociological Perspectives 43(4):671-98.

Jones, Katherine Castiello, Joya Misra, and K. McCurley. 2013. Intersectionality in Sociology. Retrieved October 29, 2019 (https://socwomen.org/wp-content/uploads/2018/03/swsfactsheet_intersectionality.pdf).

Krishnan, Preethi and Mangala Subramaniam. 2014. "Understanding the State: Right to Food Campaign in India." The Global South 8(2):101-18.

McAdam, Doug. 1999. Political Process and the Development of Black Insurgency, 1930-1970. Chicago: University of Chicago.

McCammon, Holly J., Lyndi Hewitt, and Sandy Smith. 2004. "No Weapon Save Argument': Strategic Frame Amplification in the US Woman Suffrage Movements.” The Sociological Quarterly 45(3):529556.

McCammon, Holly J., Courtney Sanders Muse, Harmony D. Newman, and Teresa M. Terrell. 2007. "Movement Framing and Discursive Opportunity Structures: The Political Successes of the US Women's Jury Movements." American Sociological Review 72(5):725-749

McCammon, Holly J. 2012. The US Women's Jury Movements and Strategic Adaptation: A More Just Verdict. New York: Cambridge University Press.

McCarthy, John D. and Mayer N. Zald. 1977. "Resource Mobilization and Social Movements: A Partial Theory." American Journal of Sociology 82(6):1212-41.

McKane, Rachel G. and Holly J. McCammon. 2018. "Why We March: The Role of Grievances, Threats, and Movement Organizational Resources in the 2017 Women's Marches." Mobilization: An International Quarterly 23(4):401-424.

Muthusamy, M. S. 1988. K. Kamaraj: A Socio-Political Study. Madras: Tamil Nadu Academy of Political 
Science.

Noakes, John A. 2000. "Official Frames in Social Movement Theory: The FBI, HUAC, and the Communist Threat in Hollywood.” The Sociological Quarterly 41(4):657-680.

Narayanan, Sudha. 2008. “Employment Guarantee, Women's Work and Childcare.” Economic and Political Weekly 43(9):10-13.

Oliver, Pamela, and Hank Johnston. 2000. "What a Good Idea! Ideologies and Frames in Social Movement Research.” Mobilization: An International Quarterly 5(1):37-54.

Ponnaiah, P. 2018. SSA, Tamil Nadu: Statistics on Schools by School Management. Retrieved 4th, May 2020 (https://tn.data.gov.in/resources/ssa-tamil-nadu-statistics-schools-school-management)

Palriwala, Rajni and N. Neetha. 2010. "Care Arrangements and Bargains: Anganwadi and Paid Domestic Workers in India." International Labour Review 149(4):511-27.

Polletta, Francesca, and Kai M. Ho. 2006. "Frames and Their Consequences." Pp. 187-209 in The Oxford Handbook of Contextual Political Analysis, edited by Robert E. Goodin and Charles Tilly. Oxford: Oxford University Press.

Rajagopalan, S.S. 2004. Removing Thatched Roofs Is Not the Solution: Interview with Dr.S.S.Rajagopalan by Asha Krishnakumar. Retrieved May 4, 2020 (https://frontline.thehindu.com/coverstory/article30224064.ece\#!)

Rajivan, Anuradha Khati. 2006. "ICDS with a Difference.” Economic and Political Weekly 41(34):3684-88.

Razavi, Shahra. 2007. The Political and Social Economy of Care in a Development Context: Conceptual Issues, Research Questions and Policy Options. 3. Geneva, Switzerland: United Nations Research Institute for Social Development.

Risman, Barbara J. 2004. “Gender as a Social Structure: Theory Wrestling with Activism.” Gender \& Society 18(4):429-450.

Roberts, Dorothy and Sujatha Jesudason. 2013. "Movement Intersectionality: The Case of Race, Gender, Disability, and Genetic Technologies." Du Bois Review 10(2):313-28.

Roy, William G. 2010 Reds, Whites, and Blues: Social movements, Folk music, and Race in the United States. Oxford and Princeton: Princeton University Press.

Scott, Joan W. 1986. "Gender: A Useful Category of Historical Analysis.” The American Historical Review 91(5):1053-1075

Simmons, Erica. 2014. "Grievances Do Matter in Mobilization.” Theory and Society 43(5):513-546.

Sivaraman, Mythily. 2013. Haunted by Fire: Essays on Caste, Class, Exploitation and Emancipation. New Delhi: LeftWord Books.

Skotnicki, Tad. 2019. "Unseen Suffering: Slow Violence and the Phenomenological Structure of Social Problems." Theory and Society 48(2):299-323.

Smelser, Neil J. 1962. Theory of Collective Behavior. New York: Free Press.

Snow, David A. and Robert D. Benford. 1992. "Master Frames and Cycles of Protest." Pp. 133-55 in Frontiers in Social Movement Theory, edited by Aldon. D. Morris and Carol McClurg Mueller. New Haven and London: Yale University Press.

Snow, David, and Robert D. Benford. 2005. "Clarifying the Relationship between Framing and Ideology." Pp. 205-12 in Frames of Protest: Social Movements and the Framing Process, edited by Hank Johnston and John A. Noakes. Maryland: Rowman \& Littlefield Publishers.

Subramaniam, Mangala and Preethi Krishnan. 2019. "Intersections of Gender, Caste, and Class: Agenda Building in the Indian Women's Movement.” Pp. 55-65 in Women's and Gender Studies in India: Crossings, edited by Anu Aneja. Oxford and New York: Routledge India.

Tarrow, Sidney. 2011. Power in Movement: Social Movements and Contentious Politics. Chicago and London: Cambridge University Press.

Terriquez, Veronica. 2015. "Intersectional Mobilization, Social Movement Spillover, and Queer Youth Leadership in the Immigrant Rights Movement." Social Problems 62(3):343-362.

Terriquez, Veronica, Tizoc Brenes, and Abdiel Lopez. 2018. "Intersectionality as a Multipurpose Collective Action Frame: The Case of the Undocumented Youth Movement." Ethnicities 18(2):260-76.

Thorat, Sukhdeo and Joel Lee. 2005. "Caste Discrimination and Food Security Programmes." Economic and Political Weekly 40(39):4198-4201.

Tilly, Charles. 1998. Durable Inequality. Berkeley and LA: University of California Press.

Vijayabaskar, M. 2011. "Global Crises, Welfare Provision and Coping Strategies of Labour in Tiruppur." Economic and Political Weekly 46(22):38-45.

Vivek, S. 2015. Delivering Public Services Effectively: Tamil Nadu and Beyond. New Delhi: Oxford University Press.

Wyatt, Andrew. 2013. "Combining Clientelist and Programmatic Politics in Tamil Nadu, South India." Commonwealth \& Comparative Politics 51(1):27-55 